\title{
YRITYSKOULUTUSTA YRITYSHAUTOMOIDEN KEINOIN
}

$\mathrm{K}$ TT Juhani Ylikerälä väitteli huhtikuun lopulla Helsingin kauppakorkeakoulussa tohtoriksi siitä, miten yrityshautomokokemus vaikuttaa yrittäjäuran syntyyn ja kehittämiseen. Väitös kuului yrittäjyyden ja pienyrittäjyyden johtamisen alaan.

Ylikerälä tarkasteli tutkimuksessaan yrityshautomotoimintaa yrityskoulutuksen menetelmänä. Yrityshautomo toimii yrittämisen laukaisevana, yrittämiskokeilun mahdollistavana sekä kokemusta ja rohkeutta antavana tekijänä yrittämistä suunnitteleville opiskelijoille. Koulun yhteydessä toimiva yrityshautomo antaa suhteellisen turvallisen mahdollisuuden oman yrittäjäosaamisen ja halukkuuden realistiseen kokeiluun. Se on potentiaalisen tulevan yrittäjän työharjoittelupaikka.

Kiinnostuksen yrittämiseen täytyy kuitenkin syntyä jo ennen hautomokokeilua. Koulun pitäisi herättää tämä kiinnostus ja saada siten entistä useammat opiskelijat mukaan hautomotoimintaan. Yrittämistä uravaihtoehtona olisi tuotava näkyvämmin esiin, ja yrityshautomon tulisi toimia integroituna osana koulun muuta yrittäjäkoulutusta. Tutkimuksessa hahmoteltu uusi yrittämisen opetusohjelmamalli tarjoaa esimerkkiratkaisun koulutuksen toteutukseen.

\section{URAKEHITYS VAUHDITTUU MYÖS TOISEN PALVELUKSESSA}

Hautomoyrittäjille yrittäminen ei ole ainoa ja eh- doton vaihtoehto, vaan se kilpailee hyvän palkkatyön kanssa. Hautomoyrittäminen on edistänyt urakehitystä myös toisen palveluksessa; eteneminen uralla on nopeampaa kuin ilman hautomokokemusta.

Pysyvämpää ja menestyvämpää yrittämistä näyttää syntyvän vasta toisen tai useamman liikeidean avulla. Tutkimuksen mukaan olisikin tärkeää saada aloittelevat yrittäjät miettimään uusia liikeideoita ja muodostamaan ns. ideapolku.

Vaikka hautomosta ei välittömästi jatkettaisi yrittäjänä, voidaan yrittäjäksi ryhtyä myöhemmin, kun hyvä idea löytyy. Tässä mielessä hautomon vaikutukset voivat ilmetä vasta myöhemmin; uskalletaan helpommin ryhtyä yrittämään uudelleen, kun omat kyvyt on havaittu ja koettu riittäviksi.

Tutkimuksessa tarkastellaan yrityshautomon käyttöä yrittäjäkoulutuksen menetelmänä ammattikorkeakoulu-, erityisesti liiketalouden alan ammattikorkeakouluympäristössä. Empiirisen ainieston muodostavat Helsingin Liiketalouden ammattikorkeakoulun yrityshautomotoimintaan osallistuneet tradenomiopiskelijat. Tutkimuksen teoriaperusta rakentuu yrittäjyyskoulutusta, -koulutuskokeiluja ja yhrityshautomotoimintaa koskevalle tutkimukselle. Metodologisesti työ oncase-tutkimus. 